\title{
For Whom We Must Speak: Devising Actos for Undocumented Farmworkers
}

\author{
Annette H. Levine and Debra A. Castillo
}

Ever tried. Ever failed. No matter. Try again. Fail again. Fail better. —Samuel Beckett, Worstward Ho (1983)

In Spring 2015, Ithaca College's IC Teatro (advised by Annette Levine), Cornell University's Teatrotaller (Debra Castillo), the Teatro Travieso theatre company (Jimmy Noriega at College of Wooster), and Dartmouth College's Analola Santana decided to collaborate on a homage to Teatro Campesino by working with our students to study the history of this important group, the current issues facing immigrant youth in our area, and devising new actos for presentation in our various communities. ${ }^{1}$ It was an ambitious project, including not only collaboration among the four institutions and significant travel to share our work with each other, but also, conceptually at least, collaboration as well with Central New York farmworkers. We called our joint project "Teatro y activismo." Our students presented their work in the context of the Middle Atlantic Council on Latin American Studies (MACLAS) conference in downtown Ithaca, as well as outdoors, on the campus grounds of the College of Wooster and Dartmouth College, and at a farmworker social in upstate New York. We were adamant that we did not want this work to be presented in a formal university setting, and never on a stage.

In this article, we want to ponder this collaboration, especially focusing on the two institutions that were able to collaborate more closely due to our proximity (Cornell University and Ithaca College are located in the same small upstate city). The curricular parallels between Teatrotaller and IC Teatro, reflections on the creative process and experiences traveling and presenting 
our actos in diverse settings allow for an exploration of what it means for our students to create devised work in this particular social justice context, where the central organizing problematic of the project requires them to speak, and moreover to speak for someone who often is in no political or social position to speak for themselves, in full cognizance of the implications of speaking out in this artificial and ventriloquized manner. We are, in essence, setting our students up for an impossible task.

Most of the journal articles dedicated to devised drama with social justice goals take a similar form. They include anecdotes, lessons from the field learned by both students and faculty, descriptions of learning outcomes and student evaluations, a recounting of enthusiastic audience response, a cautionary aside, and generally a note of self praise: this is the best project ever, bringing awareness of an important issue, and it has profoundly changed people's lives. So let us get this out of the way immediately; this was a flawed proposal, only partly successful. We took it on in an unwarranted spirit of optimism, despite knowing that current conditions in our area made extensive fieldwork and consultation impossible due to the current climate of fear among local migrant farmworkers. However, we offer this commentary in a spirit of humility, knowing that many of our colleagues (perhaps most of us) have dealt with qualified success more often than not, and that the pedagogical lessons of risking failure, perhaps even courting failure, and learning, as Beckett says, to fail better, are urgently needed.

Since the time of the Bracero program in the 1940s, the US has imaginarily conceived of the undocumented worker as primarily a male Mexican citizen who works picking fruits and vegetables in California and the Midwest. This group, we all know (or think we know), was the core body of workers radicalized by the United Farmworkers Union in the 1960s, and that movement served as the breeding ground as well for Teatro Campesino, the California-based group that celebrated its $50^{\text {th }}$ anniversary in 2015 . Today, very comprehensive recent PEW studies give us a sense of perspective: only about $4 \%$ of undocumented immigrants in the USA work now on farms, in fisheries, or forestry, while at the same time $26 \%$ of those employed in these areas are undocumented. Thus, while farmworkers have an increasingly small representation in immigrant labor overall, they loom large in the cultural imaginary and remain over-represented with respect to the total number of workers in that sector. It is worth remembering, though, that over $25 \%$ of New York State is farmland, and while most of the new immigrant workers in the state, here as everywhere else in the country, head for the city, ${ }^{2}$ according 
to Cornell Farmworker Program estimates, there are approximately 50,00065,000 undocumented farmworkers in our upstate area; 75-95\% of them from either Guatemala or Mexico, most of them living in the state year round, most of them in roughly the same age range as our undergraduate students, but with less than $20 \%$ of them speaking any English at all. In rural upstate New York, where Levine and Castillo teach, the presence of immigrant workers, in dairy and multiple fruit and vegetable farms - apples, grapes, cherries, cabbage, and sweet corn - is patent. In an unexpected corollary, in the summer of 2014 the Central American youth immigrant crisis at the southern border was having an impact on our backyard as well, when Syracuse mayor Stephanie Miner was informed by the Department of Health and Human Services that they were assessing the ex-Sisters of Saint Francis convent at 2500 Grant Blvd as temporary housing for some of them, provoking a series of town meetings and intense debate both for and against bringing in a large number of Central American youth (Hesse).

Thus, it was wholly to be expected that in the $50^{\text {th }}$ anniversary year of the foundation of Teatro Campesino we would be inspired to pay homage to their work by creating new actos with our students for presentation to local communities. We had some reason to be optimistic. While this was a new audience for IC Teatro, Cornell University's Teatrotaller has had some experience in working with this population in the past; we had a successful collaboration with the upstate Farmworker Women's Association, in a collaborative testimonial project spearheaded by Hobart and William Smith professor Alejandra Molina (a Cornell graduate), in which we created an original play, based on the women's testimonials, that we performed in various sites around the area. We had also worked with the Cornell Farmworker Program and, in consultation with local farmworkers, created short educational videos on health care access, on immigrant rights, and on basic financial planning.

Nonetheless, times have rapidly changed. The increased Obama-era deportations have hit upstate hard and farmworkers are now highly reluctant — as they should be - to gather outside of work in any numbers or to risk their scant free time with strangers. When it was apparent that we were not going to be able to speak "with" our subjects due to the obstacles and potential threat to their well-being and safety, we nevertheless resisted abandoning our project. Our commitment to the larger issues behind the project remained strong. However, we were no longer focusing on ethnographically informed, applied theatre in its more traditional sense, but a devised piece about a community, which meant that we must speak, traversing a territory 
where we risked minimalizing, misrepresenting, and simplifying the experiences of our subjects. We grappled with how to reconcile issues of voice, authority, and ownership, and whether our counter hegemonic intentions could avoid reproducing the hegemony. As Cornell student Francisca Aparo (a Mexican American woman from Texas, and a leader in MeCHa) writes: "I felt especially concerned when I had to perform in front of the population we were trying to portray, in fear that our work would come across as too shallow, or not fully encompassing of their experience. My ultimate fear was insulting or misrepresenting the population we were trying to portray through the group's writing and acting."

Without direct access to our subjects, except for the few students who had already been participating in Cornell's Friends of Farmworkers and Ithaca College's Intercambios student groups and who could not in that context conduct the kind of theatrically-grounded fieldwork we had originally imagined, the ethnographic element of the project was largely lost and our ship was adrift with no projected course. Instead, we facilitated discussions, lectures, and readings for our students as they sought out other means of engaging the issues of farmworker realities in New York State. Many of the Cornell students, who came from urban immigrant backgrounds, inevitably had recourse to their own life experiences and family histories, keeping the social justice goals outlined in the activist emphasis of the project, but moving the focus of their work away from rural realities to the experience of urban Latinos/as. We adjusted our readings to include urban realities as well, then tried to get out of their way and let them create together. ${ }^{3}$

In both Cornell and Ithaca College, the students could earn credit for their work on this project by way of a course (the Cornell student group is also open to the community as a club, and one of the key members in the small traveling group for Spring 2015 was a local high school student). At Ithaca College, Teatro: Performance and Production is housed in the Spanish Program; at Cornell, Latino Theatre Production is anchored in the Latino/a Studies Program. Both courses draw students with a diverse set of interests and skills, and neither course requires prior theatre or acting experience. The core group at Ithaca College that semester included students majoring in Journalism, Psychology, Spanish, Culture and Communication, Television and Radio, and Theatre Studies. They enrolled in the one-credit class with the awareness that they were going to be involved in the Teatro Campesino project, though none of them had prior knowledge of Teatro Campesino. They were curious about the reality of migrant farmworkers in the Central New 
York area and held an interest in social justice; some had prior activist and community-organizing experience and others had none at all.

Almost all of the Cornell students were first or second generation Latinos and Latinas for whom the social issues around immigration were important, intimate parts of their families' daily lives, although none of them came from a rural background. A critical core of them were $\mathrm{MeCHa}$ members, dedicated to activism around DACA and Dreamers support groups. Several of them were Performing and Media Arts majors, disillusioned with the lack of diverse opportunities and attention to social justice issues in Cornell's regular performance season; others were students whose majors ranged from biological sciences to literary study, social entrepreneurship, sociology, and pre-law.

In the spirit of Teatro Campesino, the students were inspired by the slogan "Todos somos teatro" and given a crash course in the origins and evolution of the movement, central concepts of theatre for social justice, and core ideas from Boal's theatre of the oppressed. We hoped to create a cointentional experience, following Freire, who argues against a "banking" model of pedagogy in favor of a more dialogic mode of learning, and if we did not initially notice that we were steering a curriculum of Border Pedagogy (Giroux), we soon realized that we had the ingredients for such an experiment. The title of this article, "For Whom We Must Speak," then, may make us squirm, but it forcefully puts us and our students into a context where we are continually asked to re-evaluate our knowledge and our privilege. It suggests that, even with the best intentions, activists may find ourselves unintentionally speaking for our subjects, thus further relegating their voices, the subjugated voices and experiences of migrant and undocumented farmworkers, to the margins. It suggests that we have appropriated their stories as our own, and though we had good intentions, that we have fallen into the trap of reaffirming our status in the hegemonic power structures and discourses critiqued by many, including bell hooks in her essay "Choosing the Margin as a Space of Radical Openness," where she articulates how speech about the "Other" often annihilates and erases:

No need to hear your voice. Only tell me about your pain. I want to know your story. And then I will tell it back to you in a new way. Tell it back to you in such a way that it has become mine, my own. Re-writing you, I write myself anew. I am still author, authority. I am still [the] colonizer, the speaking subject, and you are now at the center of my talk. (152)

Far better to put it on the table and address this danger directly. In a parallel vein, we take note of James C. Scott, when he writes that "legibility is a 
condition of manipulation" (Seeing Like a State 183), arguing that certain subjects actively resist legibility since they find themselves more subject to potential manipulation and loss of control over their lives in the measure that they become visible to the state. When we speak for these others, are we speaking against them rather than with them? Where does our obligation to revelation meet their need for silence?

Following the advice of thinkers like Judith Halberstam, we emphatically encouraged getting lost over prematurely defining our way, and thinking small so as to define a different relation to knowledge. Failure in this sense, says Halberstam, "can be counted within that set of oppositional tools that James C. Scott called 'the weapons of the weak," and that Halberstam talks about as the subtle resistances encoded in a "narrative about anticolonial struggle, the refusal of legibility, and an art of unbecoming" (88). In this sense, then, we are implicitly asking our students to tussle with themselves and the material as a necessary pedagogical step on the way to taking charge of their learning so as to better task them to struggle against what they think they know, to think about and respect the kinds of subjugated knowledges that have hidden from, or been masked by, powerful institutionalized forms of finding coherence.

This struggle occurs at all levels of knowledge production; theirs with their material, as well as ours, as their professors, with the structures of academia. By not giving them the easy answer, are we frustrating them unproductively, setting them up to fail? They looked to us expecting hierarchy and beseeching roles as author? director? stage manager? actor? set designer? We reminded them of the beginnings of Teatro Campesino and of our nonprescriptive methodology. Initially, they were hesitant to take action, unsure of themselves, fearful of the freedom we proposed. We did our best to assure them and provide sufficient guidance and ground rules to support their decisions. Eventually, Cornell workshopped and developed student-generated scripts that were given performative shape by student-chosen directors; Ithaca College students co-created their scripts and did without directors entirely, working on a group consensus model.

Curiously, all of the students in both Cornell and Ithaca College, despite their very uneven exposure to theatre conventions, had a deeply rooted, if unexplored, idea of what theatre is, based precisely on the kinds of disciplinary and institutional models we were overtly attempting to disrupt. They felt almost compulsively drawn to incorporate the more traditional notions that they associated with theatre production: the use of a stage, set, props, and 
technology. They wrote their texts and imagined blocking with a proscenium stage in mind, added cues for lighting and sound, despite the fact that we told them we would be traveling with these actos, were scheduled to perform outdoors, and would be traveling cramped in vans. We warned them that they could not expect access to what they considered essential props, could not schlepp lighting equipment, or have access to outlets for lighting and sound once we arrived at the performance sites.

Thus, while we maintained a loose authority throughout the writing and producing phases, as we would ultimately be held accountable for any issues that arose, we resisted the authoritative impulse to insist that they strike the blocking, the sound and the lighting cues in their first exploratory efforts. We valued the process of discovery as they worked with those elements and we knew that ultimately it contributed to their greater understanding and ownership of the core issues when they had to let them go. Though we anticipated they might feel betrayed upon the sudden realization that they couldn't incorporate them, we knew that they were developing a closer relationship to the creative process and to each other, and that we had given them fair warning of what to expect in the various performance spaces. In the end, as Ithaca College student Vanessa Reyes observes, "We went from 'Let's wait for instruction' to actually taking action and creating and adapting what was already written and how fearless everyone was just putting it all out there. It's just really cool." Ithaca College student Max Ocean acknowledged the process of discovery that took place: "It's difficult working collectively like that because it's not an authoritarian role of a director like you would traditionally have. It's everyone's opinion clashing and coalescing into a final vision, which is what's great about this type of theatre and what's really difficult at the same time. I think having to adapt to the circumstance like we have, especially not having the technology, was really positive and helped us find the soul of the play that had been lost."

Each of the performances failed productively in different ways. Two of the outside performances (at Wooster and Dartmouth) occurred on days that coincidentally had adverse weather. Reminder: Teatro Campesino did its important outdoor work in southern California, where it can be counted on to be 75 degrees and sunny; the northeast in April can still be late winter, with bonechilling cold, meaning that potential audience members are hurrying to get out of the cold, and are less likely to pause for an unexpected performative event. Additionally and unexpectedly, in Dartmouth the students were competing with the local lumberjack competition occurring just adjacent to us in the same 
park. This would seem to create a positive opportunity for grabbing an audience; in practice, however, our students found it very challenging to interpose themselves in ways that would distract a determined spectator from the joys of wood chopping and the noise of chainsaws. One of the important realizations was learning to adapt their expectations to an indifferent or distracted audience, one that might stop by in the middle of the play, or leave before the end. Cornell student Francisca Aparo writes: "The outdoor space allows for a unique freedom from what the playwright's original intentions are when imagining that their play might be performed indoors and with a constant presence of an audience. In this style, it is not the case that your play will have a large audience, but it is up to your actors to improvise depending on which type of outdoor context they find themselves in, in order to explore acting methods in which they can attract and hold the attention of crowds or individuals as they are walking by." Likewise, Cornell student Julian Montijo reflects: "Adaptability is what was key to many of the original performances, and it was their relentlessness that made them so successful in orchestrating a movement. For my play to have a greater impact, it needs to be more poignant and site specific and flexible. Each of the performance spaces has been so drastically different from the next, with different intended audiences, and different intended reactions, that it seems almost necessary to rewrite or reformat the plays as they move along from one space to the next." It goes without saying that this kind of profound knowledge of their material, comfortable professional working relations with each other, and the technical skills to improvise, were beyond the scope of these novice performers.

The day of the farmworker social was perfect weather, but other circumstances meant the event had a smaller constituency and a more improvisational air than originally expected: several farmworkers had recently been deported, and fear was high, prompting some folks to stay home; others could not get off from work that day; the farmworker band had broken up because a couple of members had left the state; the karaoke wasn't working properly. There was, however, a solid attendance including men, women, and children; there were games, music, and pick-up soccer, and excellent food made by one of the local Latino caterers, whose own social justice commitments led her to give us ample portions at a modest price. Julian Montijo, one of the Cornell students, a member of Friends of Farmworkers, and author of "Las dos caras del conductor," was very familiar with the local farmworker population, and in his play was writing about a challenge they face continually, the difficult and fraught negotiations with the "raitero" who charges exorbitant fees to 


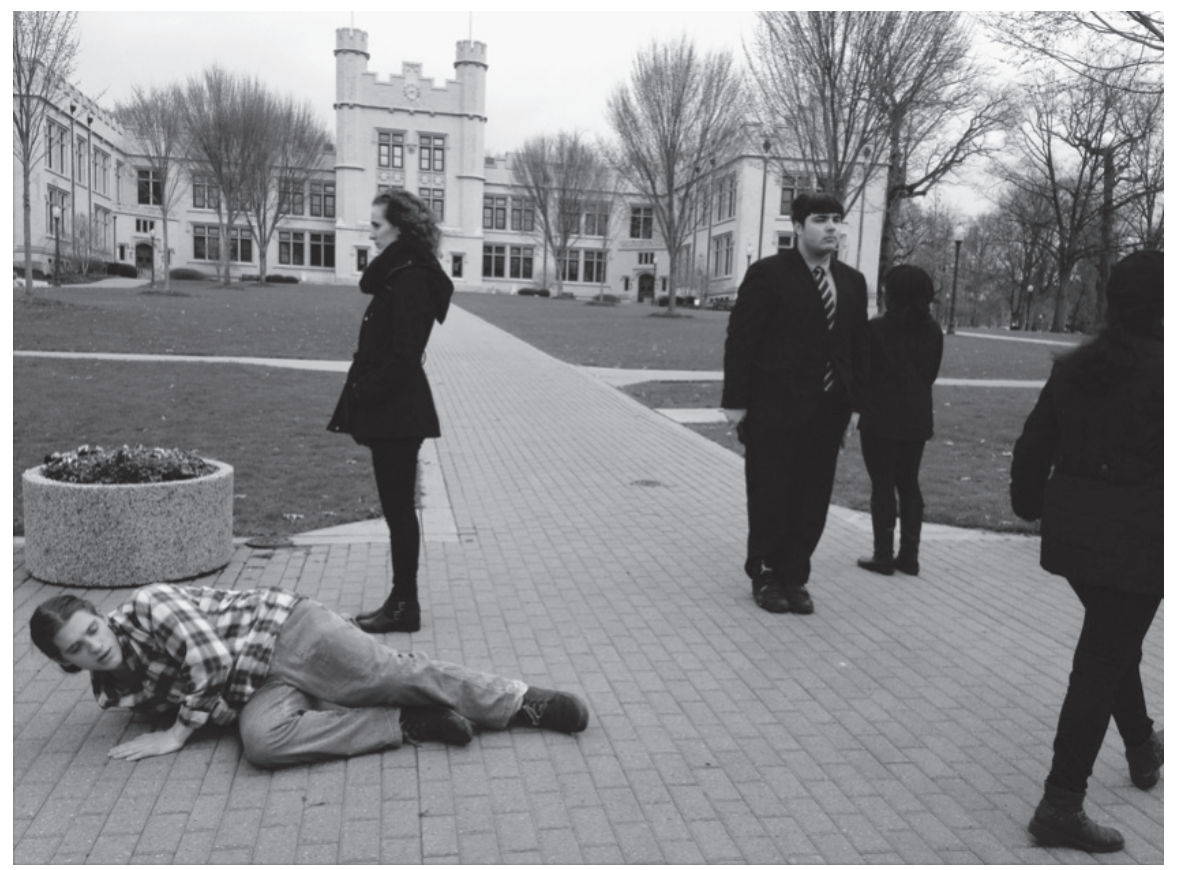

IC Teatro performing "Las noticias" on the College of Wooster campus.

From L to R: Max Ocean, Emma Rizzo, Eddie Dowd, Ria Hall, Linette Goris Jaquez.

bring farmworkers to town for their necessary shopping. Having worked with this population, he wrote the play for them, knowing that they speak very little if any English. Yet, during the process of writing and workshopping the play, he - perhaps inadvertently - chose to put most of it in English, only to recall later, to his dismay, that his target audience would understand very little of it: "it would have been great for more of my play to be in Spanish. When speaking with some of the attendees after the show, I had to explain in Spanish what happened during my play because it was so heavily written in English." Failure - and success. Julian Montijo already had good relations with the farmworkers, and had been playing soccer with them all afternoon; thus, there was a basis for goodwill towards him and a curiosity about his play that led to other thoughtful conversations about their exploitation by raiteros, their frustration, and their inability to do anything to improve the situation, as well as brainstorming on the part of Cornell University and community attendees about a potential response to making safe, affordable rides available in the region. 


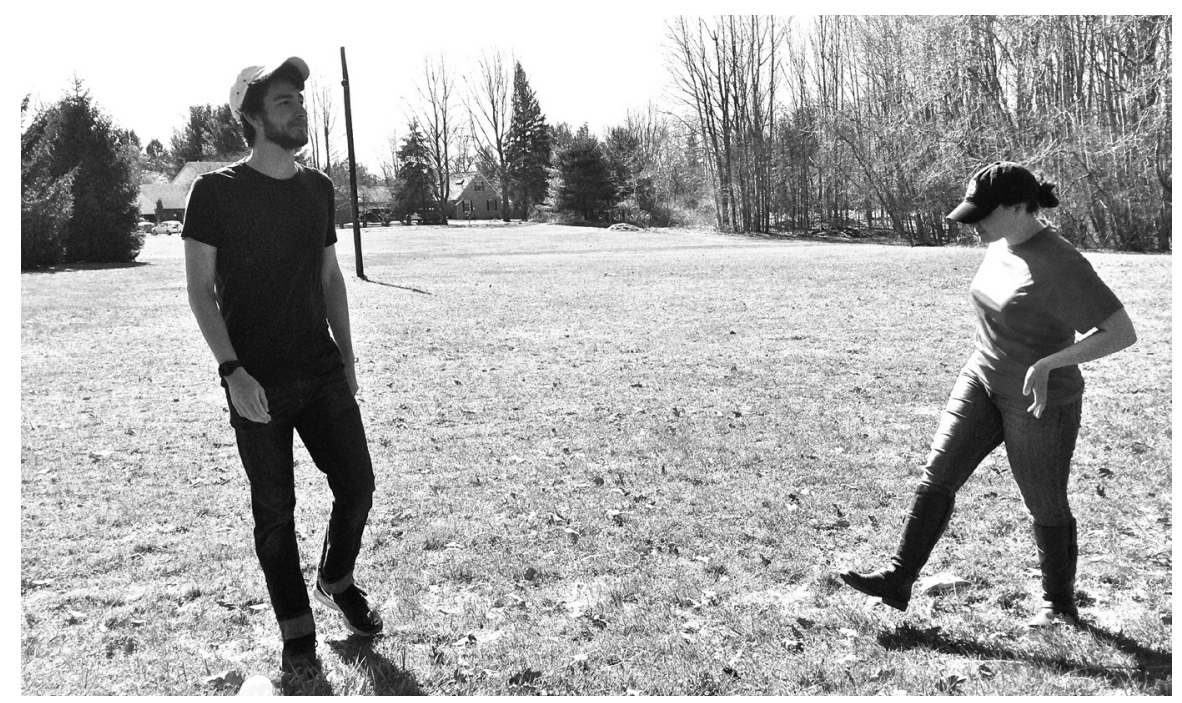

Teatrotaller's Julian Montijo and Francisca Aparo perform "Las dos caras del conductor," written by Montijo, at the Farmworker Social.

Only in the downtown Ithaca presentation, held in the gymnasium of a local community center, were the students and audience in perfect accord; an overflow crowd of mixed local community members and academics, mostly bilingual, sat attentively on chairs or the floor, watched the entire program of performances, and eagerly participated in a rich post-performance conversation with the students. Yet, from our perspective, this most comfortable of experiences for our students was also the least like the Teatro Campesino format; it failed precisely to the degree that it more closely mimicked what our students imagine as a theatrical experience.

What of the plays themselves? We conclude with two very different examples from among the plays that were fully devised for this program. The briefest of the six plays produced for this collaborative project was also the only overtly comic one (as opposed to actos that were written ironically, or with comic moments), "Español con barreras," a play on the popular English-learning DVD series "Inglés sin barreras." There is no necessary connection to farmworkers, though the members of the farmworker community who saw the play identified closely with it, since they see some of the same challenges in their school-age children. The acto begins when a Latina teenager with limited Spanish is the only one home, and has to engage in a phone conversation with her non-English speaking grandmother back 


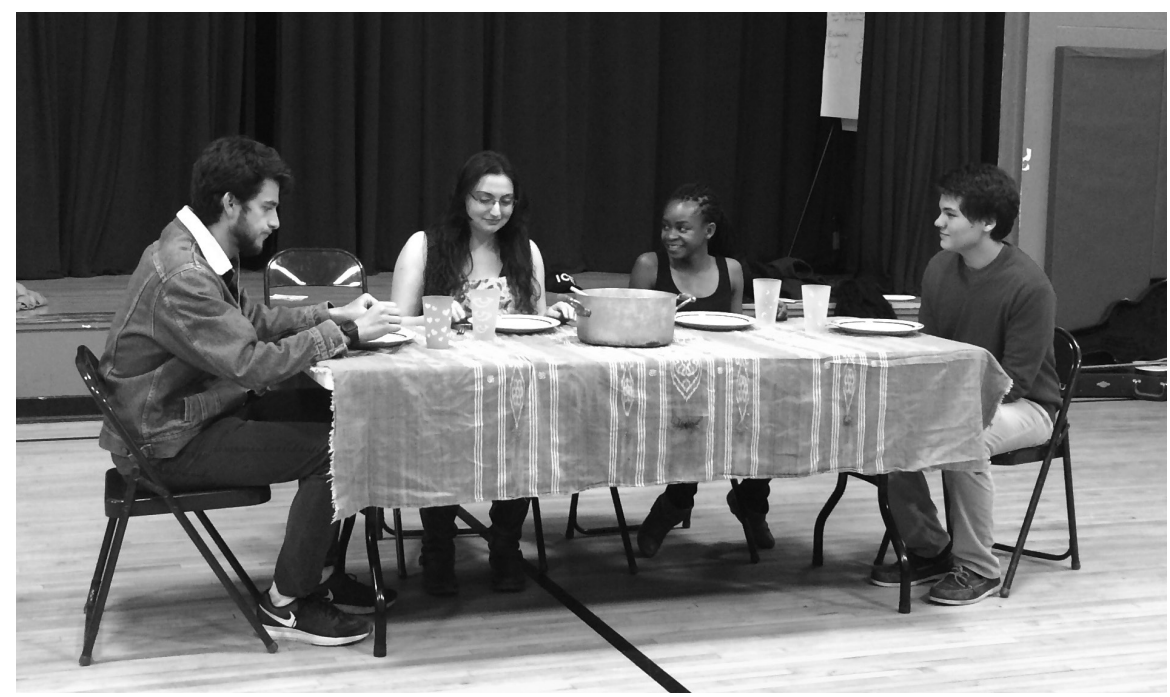

Teatrotaller's "Family" performed at the Greater Ithaca Activities Center. From L to R: Julian Montijo, Francisca Aparo, Gloria Majule, and Octavio Tellez.

home. The co-authors of this play, Michelle García and Rebeca Gallo Lazo, drew on their own experiences and their sadness over the loss of language and its effect on family relationships. For instance, Michelle writes that the play "explores the differences in languages over generations, especially since contrary to popular misconception, not all Latin@s speak Spanish. This personally resonated with me, as I began to lose my Spanish once I began elementary school and had a hard time speaking with my grandmother on the phone." For her part, Rebeca adds that while she is fluent in Spanish, her younger siblings are not, creating an enormous series of tensions with her parents, as well as in her extended family. The two of them began this project by exchanging family anecdotes in a blog, and then choosing among the anecdotes the ones that seemed to them most funny, most poignant. The text went through successive drafts in the readings Cornell students gave it, and the feedback they provided, to sharpen the humor. Rebeca notes: "We challenged our own experiences with the experiences of others. Finally, we got a combination of all our grandmothers' crazy habits and conversation points. In the end, we weaved together different stories, experiences, and moments to create one amazingly funny piece. While it was hilarious, it touched on issues that really hit close to home." 


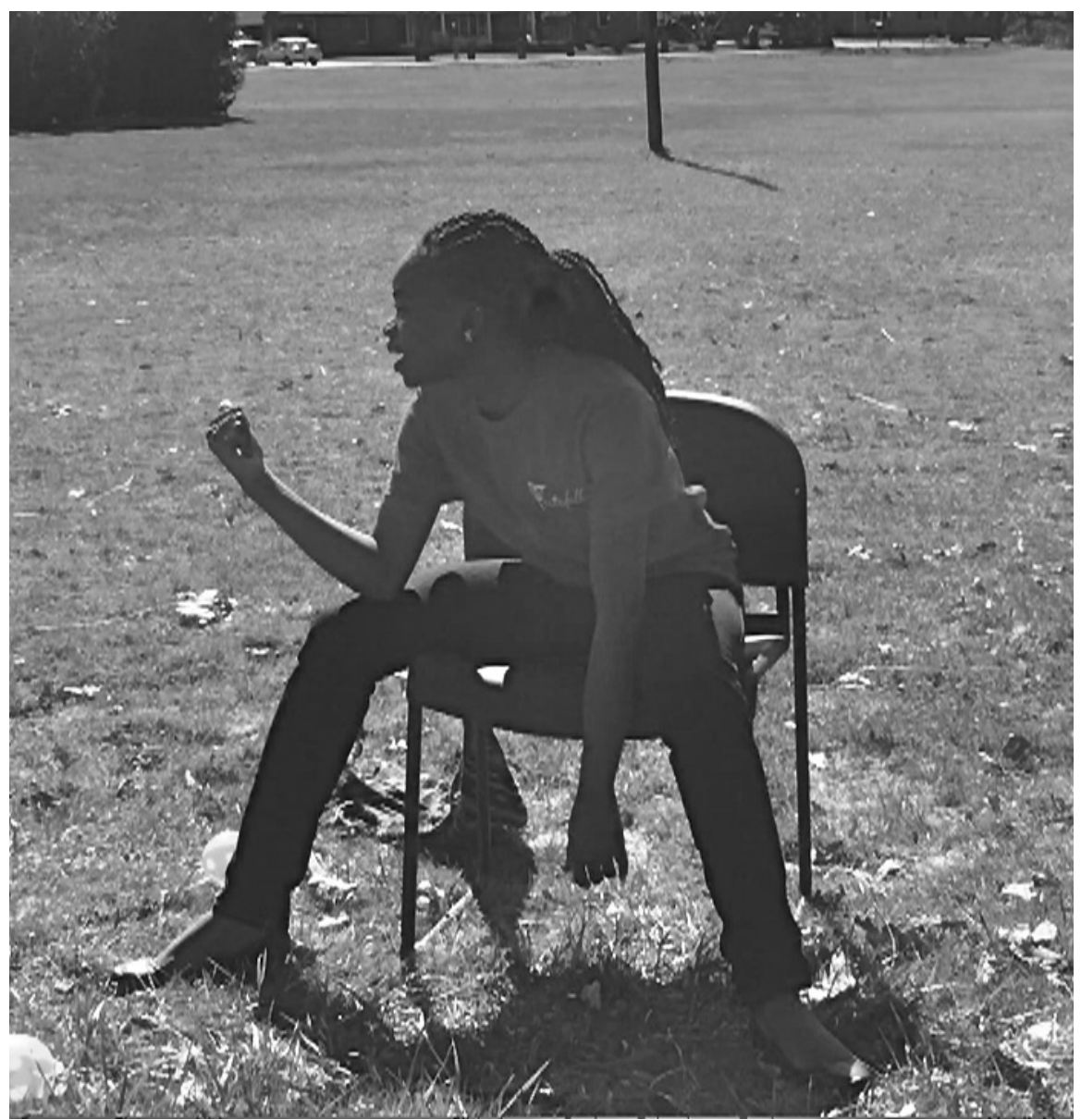

Teatrotaller's Gloria Majule performing “Español con barreras,” written by Michelle García and Rebeca Gallo Lazo, at the Farmworker Social.

Both Rebeca and Michelle had worked on devised projects with Teatrotaller before-Michelle with a scriptwriting project in collaboration with La Poderosa Media Project, Rebeca with a powerful short play about the Day Hall takeover of 1993. Yet they had never collaborated with each other, taken on such a personal topic, or done successive revisions of workshopped projects. Rebeca specifically had very mixed feelings about the final script until she saw it performed downtown in Ithaca and participated in the talk back after the show: "During the question and answer portion, I became very emotional speaking to how important Spanish has been in my life and 
how I communicate with my family. I really did not know what to expect from this work and this wasn't my favorite of my own work, but after that Q\&A, I couldn't help but think of my beautiful, dysfunctional, and loving family. This piece was for each of them, and I think that's what made it so well received. As for the future, I do not know if I will be writing plays, but I know I will always be writing my family's stories and my stories because these stories really matter."

Ithaca College students used the television screen and media portrayals of Latinos and migrant workers as their springboard for "Las noticias." They began working with the texts represented by FOX News and telenovelas. They interpreted, disrupted, and parodied those texts, rewriting them in a way that exposed the repressive forces of those cultural codes. In interrogating these texts, a number of them acknowledged that they themselves were guilty of having fallen silent to the cultural codes; that they had internalized them and become passive spectators. The acknowledgement of their own consumption of representations, in which "Others are seen as a deficit, in which the humanity of the Others is either cynically posited as problematic or ruthlessly denied" (Giroux 167), became a catalyst for the process of rewriting the texts as part of the acto.

By portraying a young couple as Others whose humanity is essentially denied through the refrain of "illegal aliens" "taking our jobs," the acto does not speak for the Other, but reveals the dehumanizing elements that further isolate and alienate. Hence, "Las noticias" tapped into the political power of theatre as a form of advocacy; that we speak to advocate for, not in place of or on behalf of. And in the process of creating and performing the acto, the students' speech act is a transformative experience that has allowed them to "locate themselves and others in histories that mobilize" (Giroux 161).

Ultimately, the acto is a critique of the spectator who consumes Fox news reports and who is easily wound up in the drama of the telenovela. Furthermore, as the parody is consumed and enjoyed by the audience, it potentially endows the spectators with agency. In "Las noticias," the spectator witnesses a celebration of community among the campesinos in a boisterous rendition of the well-known "De colores," the unofficial anthem of the Farmworker movement, but this hope is ultimately endangered by a redada that the young mother witnesses as part of a news report.

Initially, the acto concluded with the voices of the marginalized denouncing emasculation and dehumanization and reclaiming their humanity, ending with: "Muchas personas piensan que los inmigrantes son como 


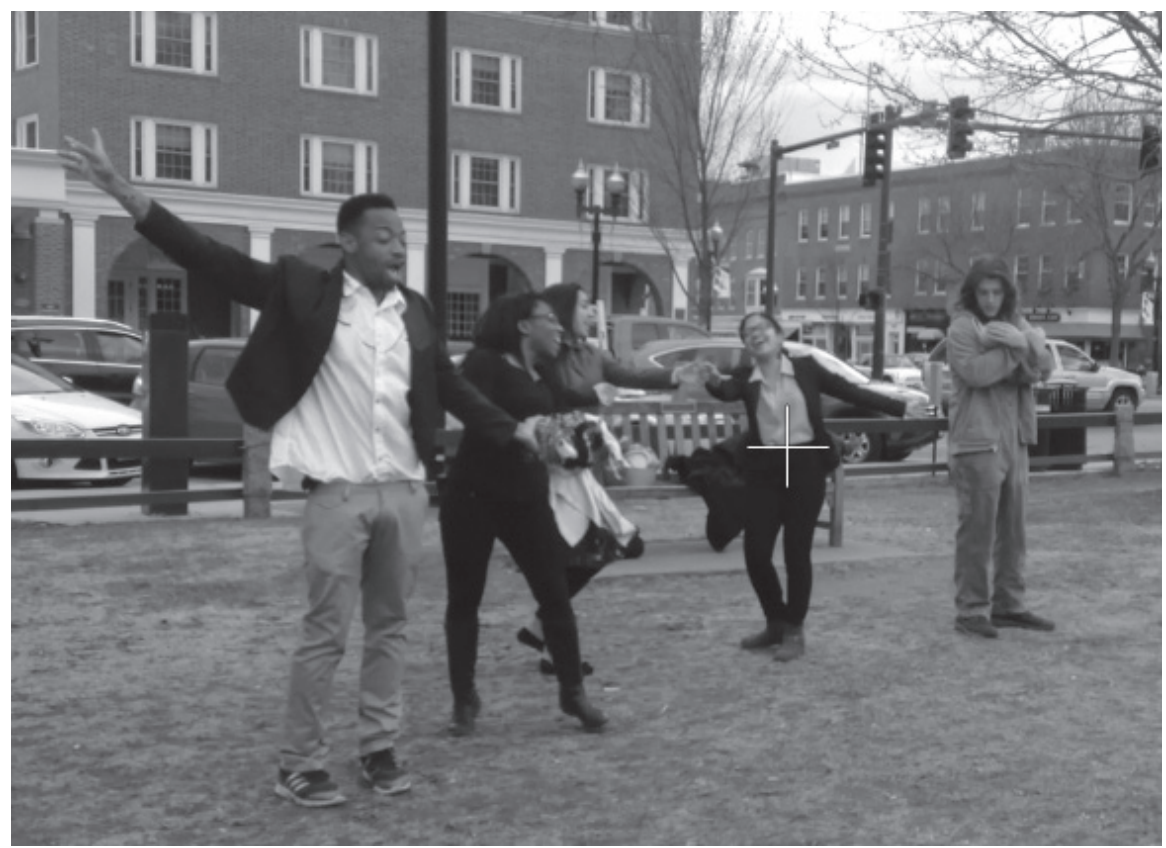

IC Teatro performing "Las noticias" at Dartmouth College. From L to R: Thomas Williams, Ria Hall, Linette Goris Jaquez, Nathiel Tejada, and Max Ocean.

animales o criminales, pero no lo somos. Somos seres humanos." Through debate and discussion, however, the Ithaca College students recognized that the ending was their own imposition; that it was the message they were advocating, but that they were speaking for the Other. While they had captured marginality as a site of resistance, their embodiment of that space yearned for acknowledgment of its inherent contradiction; they had not yet fully represented their own subject position in the drama. While they initially resisted putting themselves on stage, driven by the shame associated with their privilege, they devised an ending that affirmed themselves as speaking subjects, that put the spectator's own hegemonic subject position in question. In the final version, "Las noticias" concludes with two of the actors seated in the audience, choosing to change the channel to view something more appealing, thus revealing the spectators' agency and the use of the metaphor associated with holding the remote control, the power to simply change the channel to find something "more entertaining."

Though we are still contemplating the process and the final product, weighing the efficacy of the transgressions, student testimonials from follow- 
up interviews they conducted with one another and reports they submitted to us do reveal, at the very least, that the process shifted their perceptions of the potential impact of theatre, their own potential as a collective, as artists, and as active participants, not just spectators but spect-actors in the Boalian sense. Our students realized that, finally, while their activist goals may involve sharing knowledge with others, their most important obligation is to their own learning, to be humble about their goals as they engage in a co-teaching and co-learning exercise. A first generation Latina Ithaca College student states that prior to this project, "I didn't even know that farmworkers were a thing. I didn't know about the situation of them here." Cornell student Amanda Brock notes that, particularly after the performance in the farmworker social, "I think this is such a beautiful thing because although our life paths are completely different, the life experiences portrayed in the skits allow us, the performers, and the farmworkers to connect, reminding us of the humanity that we share." For Ithaca College student Thomas Williams, portraying the life of an undocumented worker in "La familia moderna" resonated with his experiences of persecution and silence as a black male in the U.S.: "I know what it feels like to be persecuted for something that I have no control over [...] No I don't know the particular specific struggles of somebody that identifies as an undocumented immigrant does go through, but I do understand persecution and struggle as a person of color, and I was able to draw on that."

Ultimately, the creation and performance of the actos in different spaces, and particularly their performance in unrehearsed spaces, has underscored the value of the unfinished text and its perpetual becoming. The instability of the constant reimagining of the actos' performances resists fossilization and thus instigates a process of continual rewriting and reevaluation of selves and scripts, of continued attempts to fail better.

Annette H. Levine

Ithaca College

Debra A. Castillo

Cornell University

\section{Notes}

1 Because Analola Santana was on leave in Spring 2015, she did not work with her students to create actos, but consulted with us throughout the whole process and organized our visit to Dartmouth. 
Teatro Travieso, under the direction of Jimmy Noriega, performed at the College of Wooster but could not travel to Ithaca or Dartmouth due to a busy travel schedule with their acclaimed production of "Women of Ciudad Juárez." Noriega's coordination of the Wooster event was instrumental in providing a venue for the three theatre groups to simultaneously perform their actos in a variety of outdoor spaces on the Wooster campus.

2 New York City is the second largest Latino city in the USA, after Los Angeles, with approximately 4.5 million Latinos/as in the metropolitan area (PEW). The Mexican consulate estimates that there may be as many as one million immigrants from Mexico in the area.

3 The final productions of the collaboration included three actos each by Ithaca College and Cornell students and one by Teatro Travieso. The Ithaca College actos were "Las noticias," "La familia moderna," and "Los archivos." Cornell students created "Español con barreras," "No puede ser love," and "Las dos caras del conductor" (this last, a direct homage to Teatro Campesino, as a rewriting of the classic "Las dos caras del patroncito"). Teatro Travieso drew from Teatro de las Chicanas to create "L-A-T-I-N-O," an acto about the difficulties and obstacles that Latina/o students face in the university setting today.

\section{Works Cited}

Boal, Augusto. Theatre of the Oppressed. Trans. Charles A. and Maria-Odilia Leal McBride and Emily Fryer. London: Pluto P, 1979. Print.

Freire, Paulo. Pedagogy of the Oppressed. New York: Bloomsbury, 2012. Print. Giroux, Henry. "Border Pedagogy in the Age of Postmodernism." Pedagogy and the Politics of Hope: A Critical Reader. Boulder, CO: Westview Press, 1997. 147-63. Print.

Halberstam, Judith. The Queer Art of Failure. Durham: Duke UP, 2011. Print.

Hesse, Monica. "Two thousand miles from the border, Syracuse finds itself in the immigration debate." Washington Post. 28 July 2014. Web. 1 May 2016.

hooks, bell. "Choosing the Margin as a Space of Radical Openness." Yearning: Race, Gender, and Cultural Politics. Toronto: Between the Lines Press, 1990. 145-53. Print.

Passel, Jeffrey S. and D'Vera Cohn. “Immigrant Workers in Production, Construction Jobs Fall Since 2007: In States, Hospitality, Manufacturing and Construction are Top Industries." Washington, D.C.: Pew Research Center, March 2015. Web. 1 May 2016.

Scott, James C. Weapons of the Weak: Everyday Forms of Peasant Resistance. New Haven: Yale UP, 1987. Print. . Seeing Like a State. New Haven: Yale UP, 1999. Print. 